\title{
Academic Librarians Participate in the Selection of a Director of Libraries
}

In 1970 the library faculty of the University of Louisville elected a committee to search for and to select a director of libraries to recommend to the university administration. This activity resulted from the librarians' having achieved faculty status and from recent changes in the university's governance which established the university's libraries as an academic unit. The Library Faculty Selection Committee solicited prospective candidates from names suggested by deans of library schools and other librarians, reviewed the candidates' credentials, planned the visitation and interview of the most promising candidates, and, in consultation with representatives of the University Senate Library Committee, recommended to the administration one of the candidates for the position of director of libraries.

$\mathrm{T}$ He LibRaRy Faculty of the University of Louisville had the experience of participating recently in the search for and the selection of a new director of libraries. This was a new experience for this group of librarians, as well as for this particular university. It was a new experience for the library faculty in that none of its members had previously had such a responsibility; it was a new experience for the university in that librarians had never before been involved in the selection of the person who would direct the library system in which they are essential members. Perhaps this account of one group's experience will suggest some useful procedures and will encourage academic librarians to press for a voice in the selection of the administrator with whom they will work.

$D r$. Louise Galloway is associate professor and head, Circulation Department, University of Louisville Libraries, Louisville, Kentucky, and recent chairman of the $\mathrm{Li}$ brary Selection Committee for the Director of Libraries.
Five years ago a director of libraries was chosen at the University of Louisville with no attempt on the part of the university administration to enlist the professional opinions or expertise of the librarians in the system. At that time some of the librarians suggested that, as a group, they should communicate to the administration their views on a director's qualifications and suggest candidates; others in the group opposed such action on the grounds that it was inappropriate. The viewpoint of the latter was that the selection of a director of libraries was entirely a university administration matter. To understand why, five years later, the search for the selection of a director of libraries was primarily the responsibility of a committee of librarians in the university library system, one must understand the changes that have taken place since 1965 in the internal structure of the University of Louisville and the place these same librarians (not necessarily the same individuals) now occupy within this structure. 
Changes in the University

Structure and Governance

In fall 1965 the university completed a self-study preparatory to a review by the Southern Association of Colleges and Schools. The self-study recommended "that the library staff be given faculty status commensurate with their responsibilities, training and experience." 1 It also recommended abolishing the university Senate as it was then constituted and creating a new Senate. At the time the university Senate was a large body composed of all faculty members with the rank of assistant professor and above, and also administrative officers such as the president and vice-presidents of the university, deans and directors, and the university librarian. The self-study recommended that a new Senate be created which would be composed of a representative number of faculty elected from each academic unit, with administrative officers being ex-officio, nonvoting members.

When the self-study was nearing completion in fall 1965, a new director of libraries was appointed to succeed the retiring university librarian who had occupied this position since 1927. The new director was appointed with the rank of full professor and with tenure. On May 18,1966 , the university Board of Trustees granted professorial rank to librarians in the university library system.

Once librarians become faculty members, to which faculty within the university should they be affiliated? Without some kind of affiliation within the university structure, how were they going to be able to serve on university committees and participate in other faculty concerns? It was obvious that, as a group, it was no more logical for librarians to be a part of the faculty of one school or college within the university than of another. This situation was resolved on January 18,1968 , when the self-study recommendation for creation of a new faculty Senate was implemented.

Librarians with the rank of assistant professor and above automatically became members of the old Senate, and many of them were present during the discussions of the proposed new Senate. Since the new Senate was to be composed of representatives elected from each academic unit by the faculty of that unit (instructors and above), it became obvious that the librarians would be assured representation only if the library were designated as one of the academic units. Accordingly, the librarians recommended this action to the old Senate during its deliberations on the composition of the proposed Senate body. On January 18,1968 , a motion was made to this effect by a faculty member in the history department. It was seconded by a biology department faculty member and passed with one dissenting vote. ${ }^{2}$

The proposed framework of the new Senate was submitted to a faculty vote by mail and was approved on March 15, 1968. As a result of these several actions, the library faculty and the library as an academic unit came into being. Since that time, the library faculty has formulated a constitution and bylaws under which it operates.

At the same time these events were taking place, the manual of Organization of the University of Louisville (commonly referred to as the "Red Book") was in the process of being revised to reflect the changes in the university structure that had occurred since the 1963 edition.

The old Red Book made no provision for the selection of the university librarian, except to state that the appointment would be made by the Board of Trustees upon the recommendation of the president of the university. It did specify, however, in the case of the deans, that 
in making the recommendation for the appointment of the dean of any college or school, the President shall consult with a committee elected by the faculty of the college or school concerned. Appointment of the dean of any college or school shall be made only with the advice of a committee of the faculty of the college or school concerned. ${ }^{3}$

The library faculty recommended that the director of libraries be included in this statement.

Shortly before the chapter on personnel policies was presented to the university Senate for approval, the library faculty learned that the Red Book Revision Committee was recommending that the director of libraries appointment should be made only on the recommendation of a majority of the members of the Senate Library Committee. The library faculty communicated to the committee its disapproval and concern that librarians would have no voice in the selection of the director of their faculty unit. As a result, the proposed statement which was presented to the Senate and approved by them, by the university assembly (the governing body composed of all faculty members to which matters of university-wide concern must be referred from the Senate before faculty action is final), and by the Board of Trustees is as follows:

Appointment of the Director of Libraries shall be made only on the recommendation of a majority of a Committee of the Library Faculty in consultation with the Senate Library Committee. ${ }^{4}$

These changes made it possible for the Library Faculty to play a vital role in the search for and the selection of a new director of libraries when it was announced in mid-May 1970 that the director had resigned, effective September 1,1970 , to assume the deanship of a new graduate library school.

\section{Formation OF THE LIBRARY}

Faculty Selection Committee FOR THE Director OF LibraRIES

Shortly after the announcement of the director's resignation, the vice-president for academic affairs instructed the library faculty to formulate a Selection Committee for the director of libraries. The vice-president designated two members of the Senate Library Committee to work with the Selection Committee in a consultative capacity.

The Executive Committee of the library faculty, the director, and the interim director screened the faculty roster and proposed to the faculty a Selection Committee of nonmembers, designating three of these as the Search Sub-Committee. The faculty considered the suggestions and voted the committee as recommended. It was agreed that the committee would choose its own chairman and that the interim director would serve on the committee as an ex-officio member.

The Selection Committee was composed of librarians in both technical and public services, departmental libraries, and special collections. Some of the nine members were in administrative positions; others had no administrative responsibilities. The committee included librarians with only a few years of professional experience at the university or elsewhere, as well as librarians with a number of years of experience at the university and in other library situations.

At the June 4, 1970, meeting of the library faculty, the vice-president for academic affairs discussed the general procedures other selection committees in the university had followed in their search for deans and directors and suggested that the Library Faculty Selection Committee determine at what point and in what ways it would be most helpful to consult with the representa- 
tives of the Senate Library Committee for their suggestions and reactions. He mentioned two schools in the university that had recently been involved in the search for a new dean and suggested that information about their experiences might be helpful to the Library Faculty Selection Committee. The vice-president stated that he would be available to consult with the committee at any time, and he expressed the hope that the committee would be ready to invite candidates for interviews in the fall of 1970.

\section{Initial Committee Procedures}

On June 19 the Selection Committee held its first meeting. The committee decided that the chairman should be one of the members of the Search Sub-Committee and also the sub-committee chairman. Following the election of the chairman, the committee discussed the kinds of education and experience they felt the director of this particular library system should possess. The committee directed the Search Sub-Committee to prepare a letter to be sent to all deans and directors of library schools offering doctoral programs and to other eminent librarians throughout the country requesting names of persons who might be interested in becoming candidates. Members of the Selection Committee suggested names of eminent librarians to whom this initial letter would be sent. As the committee reported its procedures and progress to the library faculty and to the Senate Library Committee representatives, still other names were added to this list. In all, some twentyfive persons were queried for names of possible candidates.

The Selection Committee instructed the chairman to confer with the chairman of the Search Committee of the engineering school whose faculty had recently completed its search for a dean. This engineering professor provided the committee with detailed, invaluable in- formation about the engineering school's experience and the procedures they had found effective. He also shared with the committee the various form letters and informational materials his committee had developed and the schedule they had followed during the visitation and interview of candidates.

Based on the experience of the engineering school, a member of the Search Sub-Committee prepared a brief statement about the structure and characteristics of the university, the cultural aspects of the city, and the organization and extent of the university library system. The Search Committee proposed that this document be enclosed in the letter they had drafted to be sent to prospective candidates. The Selection Committee reviewed, edited, and approved the letter and the informational material.

Before the end of June the letters asking for names of possible candidates were mailed. As replies were received, letters were sent to these prospects asking if they were interested in becoming candidates and, if so, requesting that a resume of education, experience, and publications be sent to the committee. Prospects suggested by members of the library faculty and staff and other members of the university faculty were also queried.

A card record was prepared for each prospect who was suggested. This record included the prospect's name and address, by whom recommended, date initial letter of inquiry was sent, date prospect's reply was received, and whether or not the prospect wished to become a candidate. For those who declared their interest in becoming candidates, the names of the references they submitted were added to this master record and notations were made for the references who were contacted and from whom replies were received. Several persons learned of the vacancy from 
prospects who were not interested in becoming candidates and also from other sources. Some of these persons wrote directly to the committee; others wrote to the president of the university who forwarded their letters to the committee. A list of approximately seventy prospects was compiled. Of these, twenty-five expressed interest in being considered as candidates.

\section{Review of the Credentials OF THE CANDIDATES}

The Selection Committee agreed that the Search Sub-Committee should review the vitae supplied by each candidate and retain for the purview of the entire Selection Committee only those candidates whose overall qualifications appeared to meet the criteria the Selection Committee had broadly outlined for the position of director. The three members of the Search Sub-Committee agreed that any candidate reviewed favorably by one or more of them would be passed to the Selection Committee for consideration.

These procedures and the committee's progress were reported orally by the chairman to the library faculty early in July. Later in the month the committee invited the vice-president for academic affairs and the two Senate Library Committee consultants to a meeting to report on procedures and progress and to invite questions and suggestions. A detailed, written report of the structure, procedures, and progress of the Selection Committee was sent to the library faculty and staff on July 28 .

In preparation for a review of the candidate's vita, the Search Sub-Committee prepared a one-page form on which they summarized the information supplied by the candidate. Each of the three committee members took several of the candidates' resumes and prepared the summary sheets. Independently, each committee member read the in- formation supplied by each of the twenty-five candidates and rated each candidate in one of three categories: Hot, Hold, or No; and within one of these categories rated each candidate either 1,2 , or 3 , with 1 being the highest rating in each category. The committee then discussed each candidate and compared ratings. Six candidates were rated "No" by all three of the committee members. These six were dropped from further consideration. Nineteen were rated by one or more of the committee in the "Hot" or "Hold" category, and the committee then wrote to each of the references these candidates had named.

As letters were received from the candidates' references, a file was compiled on each candidate. The file contained the summary sheet of information supplied by the candidate and any additional data gleaned from Who's Who in Library Service and Library Literature, all correspondence with the candidate, his vita, letters of reference, and, in some instances, copies of some of his published articles. All of these data were duplicated for each of the ten members of the Selection Committee. Prior to the meeting when each candidate was discussed, the complete dossiers were distributed to the committee for their study and independent ratings.

Before each of the several meetings the Selection Committee held to discuss the candidates, the members were alerted as to which candidates would be reviewed during a particular session so that committee members would have all the data with them, would have recently reviewed all of the resumes, and would have rated each candidate. At the review meeting, each committee member, in turn, was given an opportunity to comment on the candidate's vita and the rating that committee members had assigned to the candidate. One member tallied the ten ratings on each candidate and arrived at a composite 
rating. This procedure was followed for each of the nineteen candidates. Some of the committee changed their initial ratings on a candidate after he had been fully discussed and his credentials compared with those of other candidates.

After all of the candidates had been reviewed, all of those with a composite rating of "Hot" or "Hold" were set aside to be screened again. The committee agreed on eight candidates who appeared most promising and continued to review these to narrow the choice to the first three to be invited for interviews.

The objective, reasoned approach each committee member made in appraising each candidate fostered a healthy climate for arriving at a consensus. In addition, there was unanimity of opinion that the person chosen for the director's position should be able and willing to work within an academic structure where the librarians are organized as a faculty with responsibilities and opportunities to share in policy and operation decisions in a manner similar to other academic units and other faculties. The committee's insistence on this qualification screened out some candidates who otherwise possessed many good qualities; it further united the committee on the choice of candidates to invite for interviews, and on its ultimate choice of a director.

Lack of agreement might have developed and been difficult to resolve had none of the committee's preferred choices responded favorably to the University of Louisville library situation and to the university itself. The committee recognized this possibility and prepared itself psychologically and operationally to reappraise the vitae of the candidates already in hand and to seek other candidates. Happily, this eventuality did not occur.

The committee members were thorough and candid in their scrutiny and comments about the candidates. Consistently, their assessments were in terms of the candidate's suitability for the position of director of libraries for this particular institution. They weighed the candidate's credentials in the light of this library system and of the future role and scope of it and of the University of Louisville, insofar as these directions are now defined or can be foreseen.

The committee was unanimous in its choice of the first three candidates it wished to invite for interviews. It was also generally agreed on the next three candidates who would be invited for interviews, if the committee did not respond favorably to the interviews with any of the first three candidates.

Early in October at a meeting with the vice-president and the two representatives of the Senate Library Committee, the Selection Committee presented the credentials of the first three candidates and the reasons the committee considered these candidates sufficiently promising to invite them for interviews. The three consultants approved the committee's choices, and dates for the interviews were tentatively scheduled for the last two weeks in October.

\section{Plans For Visitation of Candidates}

The chairman of the Selection Committee telephoned the three candidates to find out if each could come on the proposed dates. The three visits of two days each were scheduled within a twoweek period so that there would be less likelihood that the committee's impressions of each of the candidates would have lost their sharpness by the time the last one had been interviewed. In the phone call the chairman explained that, during the visit, a time was being allocated for the candidate to address the library faculty. He was asked to address his remarks to four broad questions the 
committee had formulated. He was to feel free to include in his presentation any other topics he felt were appropriate. The questions were read to the candidate during the phone call and then sent to him, along with other information materials.

To provide background information about the library system and as clear a picture as possible of its present status, each candidate was sent the following materials prior to his visit: the 1969-70 annual reports of all department heads and departmental and professional school librarians; annual reports of the director of libraries from 1956 to 1970 ; and the constitution and bylaws of the library faculty.

The committee formulated a master schedule for the candidates' visits. This schedule and the candidates' visitation dates were sent to the library faculty and staff, the two Senate Library Committee consultants, and the vice-president for academic affairs. In addition, copies of the candidates' vitae were placed in the Reference Department of the university library for the information of any member of the library faculty and staff.

In each case, the candidate was scheduled to arrive in the evening. The vice-president and the chairman of the committee met him for dinner and committee members joined them later for an informal get-together. The first day of the visit the candidate was given a brief tour of the university library and one of the departmental libraries on the same campus. He met with the Senate Library Committee and the vice-president at lunch. In the afternoon he was interviewed by the Selection Committee. At this time the candidate was given the opportunity to ask the committee questions as well as to respond to questions from committee members. At an informal tea all library staff and faculty members had an opportunity to see and meet the candidate. Later in the afternoon, some of the committee took the candidate on an automobile tour of some of the city's residential areas, other campuses of the university, and some of the professional school libraries.

The schedule for the second day of the visit began with the candidate's address to the library faculty. The library staff had requested that they be allowed to send two representatives to hear the candidate's presentation and to pose questions of staff concern. This request was welcomed as an added opportunity to keep the staff interested in and informed of the selection procedures and progress. The interim director of libraries, department heads, and the departmental and professional school librarians who comprise the Library Cabinet had further opportunity for contact with the candidate at lunch. In the afternoon the candidate met with the president of the university and with the vice-president for academic affairs.

\section{Activities Following the First Visitation}

Shortly after the candidates' visits, the Selection Committee met to share their reactions and impressions gleaned from their colleagues. The vice-president had made it clear that if, following these first visits, the committee were undecided about a choice, they should invite other candidates for interviews. If, however, they were favorably impressed and seriously interested in one candidate, they should recommend to the administration that he be invited for a second visit when he would meet the several academic deans, representative faculty members, and members of the Board of Trustees, and have further conferences with the president and the vice-president.

The Selection Committee members were unanimous in their choice of the candidate they wished to invite for a 
second visit. They met with the Senate Library Committee consultants and the vice-president who concurred with the committee's choice. Shortly, the Selection Committee sent a memorandum to the library faculty and staff about the candidate the committee was recommending that the administration invite for a second visit.

The administration took the initiative for planning the candidate's second visit which was also of two days' duration. The Selection Committee declined the administration's offer to have the candidate meet with the library faculty or staff during this return visit because of their general feeling that there had been ample opportunity during the first visit for them to have contact with the candidate.

On November 30, 1970, the Selection Committee addressed a memorandum to the vice-president unanimously recommending that the candidate be present- ed to the Board of Trustees for appointment to the position of director of libraries. The candidate was offered the position, agreed to accept it, and the vice-president notified the Selection Committee's chairman of the decision. The committee, in turn, sent a memorandum to the library faculty and staff stating that, subject to action by the Board of Trustees at its December 1970 meeting, Mr. John Demos, currently assistant director of libraries at Ohio State University, would become director of libraries at the University of Louisville on July 1 , 1971.

\section{FoOTNOTES}

1. Louisville, University, University of Louisville Self-Study Report, University Report 1:403-04.

2. Louisville, University, Minutes of the University Senate (18 Jan. 1968).

3. Louisville, University, Organization of the University of Louisville; rev. 1963, p.53.

4. Louisville, University, The Red Book; Government and Organization, University of Louisville; rev. 1971, 5.1.2.A. 